\title{
Analisa Perancangan Desalinasi Air Laut Dengan Variasi Filter Tempurung Kelapa Dan Variasi Temperatur Pemanasan
}

\author{
A. Pratama, Mesak, J. P.Mahendra. F. Rahmadianto, G. A. Pohan, E. E. Susanto \\ Teknik Mesin S-1, Institut Teknologi Nasional Malang, Kota Malang, Indonesia. \\ Email:Adhipratama2101@gmail.com
}

\begin{abstract}
Dalam penyusunan jurnal ini peneliti bermaksud untuk memberikan informasi tentang proses desalinasi air laut dengan variasi filter tempurung kelapa dan variasi temperatur pemanasan. Dengan proses desalinasi air laut dengan filter tempurung kelapa sangat menguntungkan karena mampu memberikan penurunan nilai TDS pada air laut dengan satuan PPM mg/l. Namun tidak hanya itu, desalinasi air laut sangat memberikan kontribusi untuk peningkatan nilai $\mathrm{pH}$ air laut untuk kelayakan minum. Dalam proses desalinasi dengan filter tempurung kelapa menggunakan 3 filter tempurung kelapa yang memiliki ketebalan, suhu dan holding waktu yang berbeda-beda. Dalam pengolahan data penelitian ini menggunakan metode taguchi. Selama proses pengujian ini batasannya adalah untuk mengetahui dampak filter tempurung kelapa terhadap nilai TDS dan $\mathrm{pH}$. Maka dari itu peneliti sungguh mendapatkan temuan menakjubkan dimana filter tempurung kelapa ini mampu mengurangi zat yang terkandung dalam air laut melalui uji TDS. Sehingga penulis menyimpulkan bahwa tempurung kelapa sangat penting untuk proses desalinasi air laut dalam mengurangi kadar zat yang bisa saja berbahaya dalam air laut.
\end{abstract}

Keywords tempurung kelapa, filter, desalinasi, Taguchi

Paper type Research paper

\section{Pendahuluan}

Air laut sangat diketahui betapa melimpah khususnya di negara kita Indonesia yang merupakan negara kepulauan. Air laut adalah sumber penting juga bagi kehidupan manusia, dimana pada umumnya air laut sangat berkontribusi besar bagi petani garam Indonesia. Air dengan rumus $\mathrm{H} 2 \mathrm{O}$ ini juga yang persentasenya kira-kira $70 \%$ pada permukaan bumi adalah air laut yang asin. Sangat diketahui meski dengan jumlah yang melimpah pemanfaatannya masih belum luas, seperti halnya untuk dijadikan air minum.

Dengan angka data statistik total perusahaan air besih pada tahun 2015 baru mencapai 539 perusahaan, yang kapasitas efektif produksi 167.915 liter per detik. Namun Indonesia sebagai negara kepulauan ini memiliki sumber air laut yang banyak atau melimpah, tapi kita mengetahui Indonesia sangat kekurangan air tawar yang bersih apalagi disaat musim kemarau yang panjang. Dan ini pernah terjadi pada tahun 2015 pada pertengahan September yang kita tahu ini adalah dampak dari suatu fenomena El Nino. Dampak ini meliputi beberapa wilayah yang kita tahu adalah wilayah yang tidak lepas dari jumlah daerah pantai yang luas, seperti Provinsi Bali salah satunya. Sehingga fenomena kemarau yang terjadi ini banyak masyarakat khususnya daratan timur Indonesia mengkonsumsi air tidak bersih dan menyebabkan sebagian besar masyarakat yang mengkonsumsinya terserang penyakit diare.

Dengan ini saya akan meneliti tentang pemanfaatan air laut untuk digunakan untuk air minum layak konsumsi. Penulis memikirkan sebuah gagasan bagaimana air laut dapat di olah dengan cara desalinasi. Alasan inilah yang membuat penulis harus berpikir keras dalam menciptakan sebuah eksperimen melalui prototipe untuk memanfaatkan air laut agar dapat disuling menjadi air tawar yang layak di minum.

Penulis sudah mengetahui dimana beberapa sistem penyulingan air laut dengan cara destilation memanfaatkan uap air laut menjadi air tawar. Namun penulis harus mempunyai ekperimen alat yang berbeda, dimana alat tersebut memliki kesatuan dengan wadah hasil desalinasi air laut, penulis menarik kesimpulan untuk menggunakan filter tempurung kelapa yang tentunya belum banyak orang mngetahui kegunaan tempurung kelapa tersebut yang mampu untuk menangkap organisme dalam air laut, dimana organisme ini yang mempengaruhi keasinan air laut itu sendiri. Sehingga penulis memutuskan merancang alat protipe desalinasi air laut tersebut dan penulis mengangkat tema penelitian dengan judul Analisa Perancangan Desalinasi Air Laut Dengan Variasi Filter Tempurung Kelapa Dan Variasi Temperatur Pemanasan. 


\section{Metode Penelitian}

\section{Persiapan Alat dan Bahan}

Proses mempersiapkan komponen-komponen untuk perancangan prototype alat desalinasi air laut yang berupa alat test ppm, thermometer suhu, ph digital, teko pemanas air laut, gunting, cutter, penggaris, palu/hamar, dan bahan batu lava, batu zeloit, pasir silika, arang tempurang kelapa, lem silicon, lem G china, lembaran akrilik, pvc siku.

\section{Pembuatan Prototype Alat Desalinasi Air Laut}

Proses pemasangan komponen-komponen menjadi prototype alat desalinasi air laut.

\section{Uji Coba Fungsi Prototype}

Proses uji coba fungsi prototype dengan cara menyalurkan air laut dengan variasi pemanas 1 menit, 2 menit dan 3 menit untuk memastikan alat desalinasi berfungsi dengan baik.

\section{Perlakuan Panas}

Proses pemanasan air laut yang telah dipanaskan dengan variasi temperature pemanasan $50^{\circ} \mathrm{C}, 80^{\circ} \mathrm{C}$, dan $100^{\circ} \mathrm{C}$ dan variasi penahanan pemanas 1 menit, 2 menit, dan 3 menit.

\section{Pengujian PH Air}

Pengujian PH air dilakukan dengan alat uji PH asam basa di Laboratorium.

\section{Pengolahan Data dan Pembahasan}

Proses pengolahan data dilakukan dengan cara membandingkan hasil pengujian pada spesimen yang telah diberi perlakuan berbeda untuk selanjutnya dianalisis dalam pembahasan.

Pembahasan adalah proses menganalisis data hasil pengujian berdasarkan teori-teori yang berhubungan dengan topik penelitian.

\section{Penarikan Kesimpulan}

Proses penarikan kesimpulan adalah proses akhir dari penelitian yang berisi simpulan hasil pengaruh variasi filter batu lava dan variasi temperature pemanas terhadap kemurnian air yang di desalinasi.

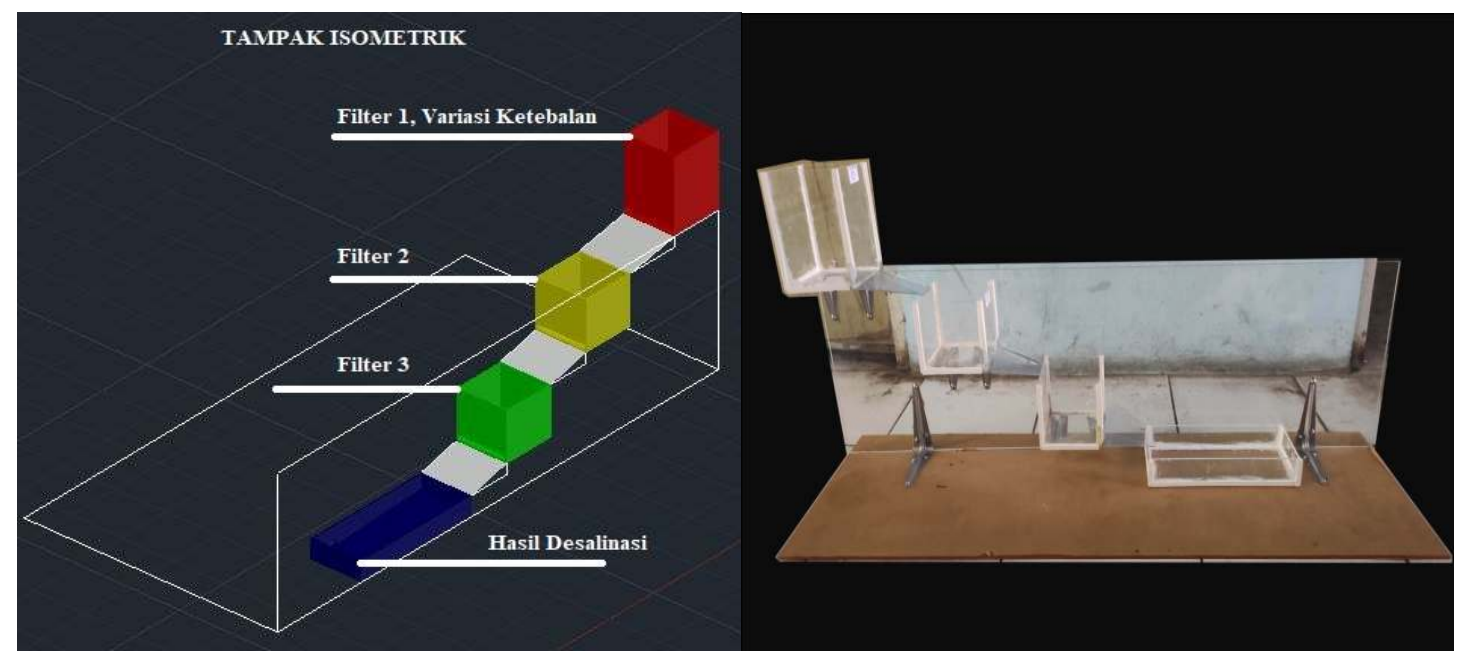

Fig. 1. Design alat desalinasi dengan Autocad 2017 


\section{Hasil dan Pembahasan}

TABLE I. DATA PENGUJIAN TDS

\begin{tabular}{ccccccc}
\hline No. & Ketebalan Filter & Pemanasan & $\begin{array}{c}\text { Holding } \\
\text { Waktu }\end{array}$ & Uji TDS 1 & Uji TDS 2 & Uji TDS 3 \\
\hline 1 & 1 & 1 & 1 & 21.720 & 16.720 & 26.720 \\
2 & 1 & 2 & 2 & 27.480 & 22.480 & 32.480 \\
3 & 1 & 3 & 3 & 26.000 & 21.000 & 31.000 \\
4 & 2 & 1 & 2 & 27.140 & 22.140 & 32.140 \\
5 & 2 & 2 & 3 & 30.680 & 25.680 & 35.680 \\
6 & 2 & 3 & 1 & 29.860 & 24.860 & 34.860 \\
7 & 3 & 1 & 3 & 34.700 & 29.700 & 39.700 \\
8 & 3 & 2 & 2 & 36.520 & 31.520 & 41.520 \\
9 & 3 & 3 & 1 & 38.740 & 33.740 & 43.740 \\
\hline
\end{tabular}

Keterangan:

\begin{tabular}{lr} 
A & Ketebalan Filter: $(1=8 \mathrm{~cm} ; 2=6 \mathrm{~cm} ; 3=4 \mathrm{~cm})$ \\
B & Pemansan: $\left(1=50^{\circ} \mathrm{C} ; 2=80^{\circ} \mathrm{C} ; 3=100^{\circ} \mathrm{C}\right)$ \\
C & Holding Waktu: $(1=1$ menit $; 2=2$ menit $; 3=3$ menit $)$ \\
\hline
\end{tabular}

TABLE II. DATA PENGUJIAN PH AIR LAUT

\begin{tabular}{ccccccc}
\hline No. & Ketebalan Filter & Pemanasan & $\begin{array}{c}\text { Holding } \\
\text { Waktu }\end{array}$ & Uji pH 1 & Uji pH 2 & Uji pH 3 \\
\hline 1 & 1 & 1 & 1 & 6.824 & 6.789 & 6.859 \\
2 & 1 & 2 & 2 & 6.555 & 6.520 & 6.590 \\
3 & 1 & 3 & 3 & 6.214 & 6.179 & 6.249 \\
4 & 2 & 1 & 2 & 6.842 & 6.807 & 6.877 \\
5 & 2 & 2 & 3 & 6.575 & 6.540 & 6.610 \\
6 & 2 & 3 & 1 & 6.467 & 6.432 & 6.502 \\
7 & 3 & 1 & 3 & 6.824 & 6.789 & 6.859 \\
8 & 3 & 2 & 2 & 6.600 & 6.565 & 6.635 \\
9 & 3 & 3 & 1 & 6.480 & 6.445 & 6.515 \\
\hline
\end{tabular}

\section{Keterangan:}

$\begin{array}{lr}\text { A } & \text { Ketebalan Filter: }(1=8 \mathrm{~cm} ; 2=6 \mathrm{~cm} ; 3=4 \mathrm{~cm}) \\ \text { B } & \text { Pemansan: }\left(1=50^{\circ} \mathrm{C} ; 2=80^{\circ} \mathrm{C} ; 3=100^{\circ} \mathrm{C}\right) \\ \text { C } & \text { Holding Waktu: }(1=1 \text { menit } ; 2=2 \text { menit } ; 3=3 \text { menit })\end{array}$

Dari gambar diatas adalah data yang digunakan dalam proses pengujian dan didapatkan 9 sample uji untuk di uji ke laboratoriun, sehingga data uji didapat Uji TDS 1-3 dan Uji pH 1-3. 


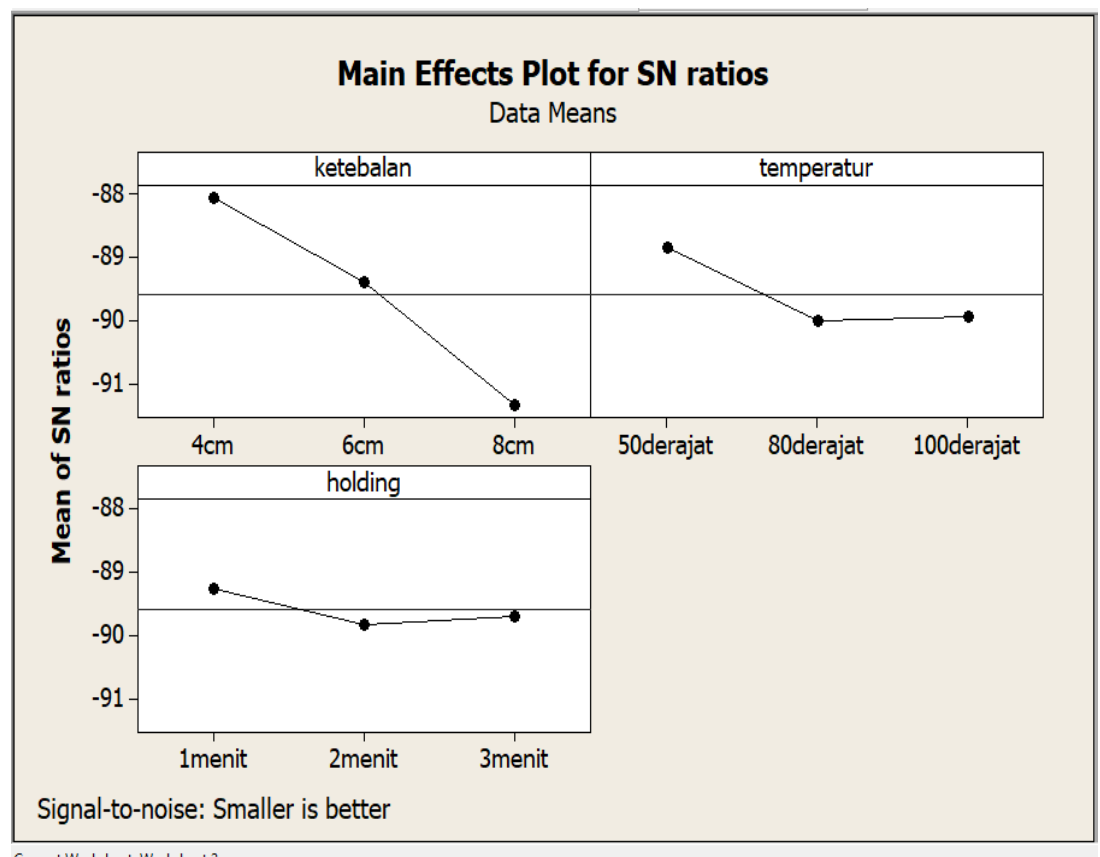

(a)

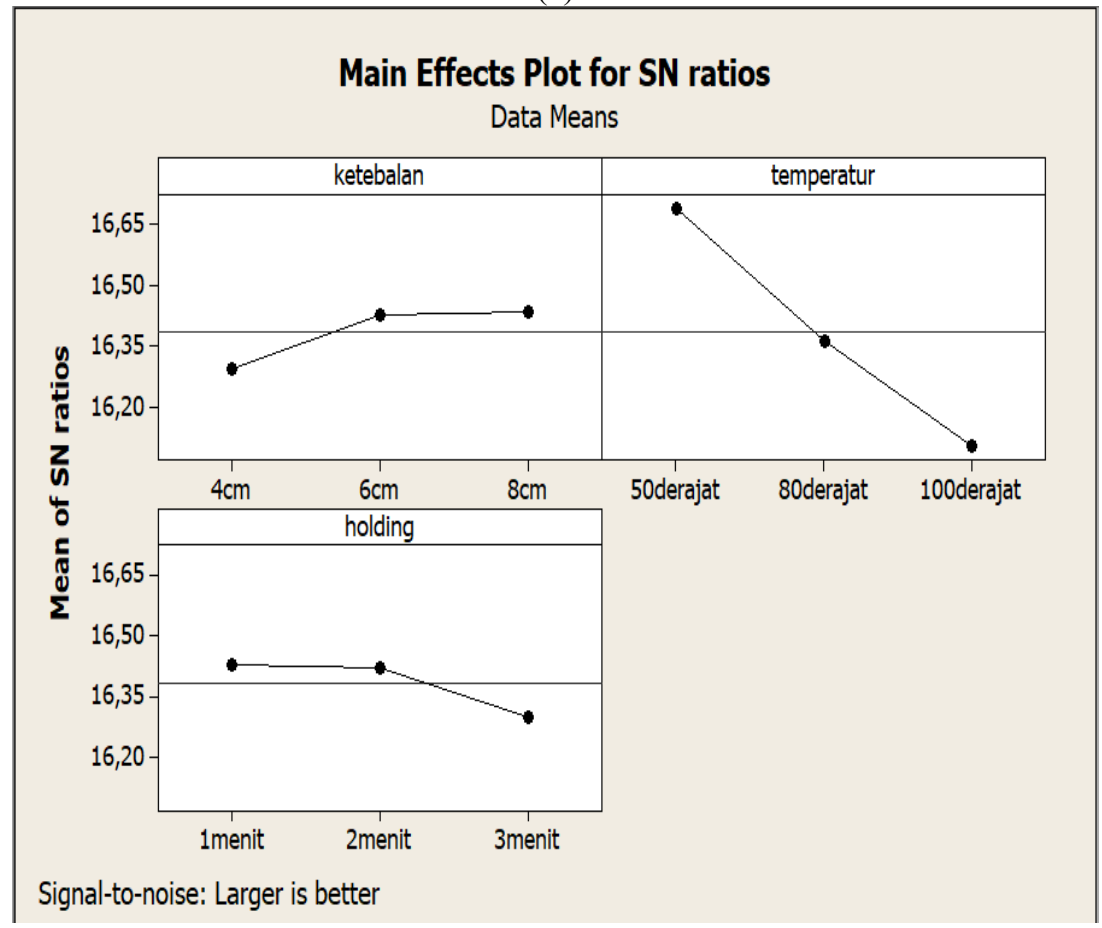

(b)

Fig. 2. Grafik (a) TDS dan (b) pH metode taguchi

Diketahui dalam pembahasan ini adalah menjelaskan tentang hasil dari penelitian yang dilakukan pada saat proses desalinasi air laut menggunakan filter tempurung kelapa yang berbeda ketebalan, suhu dan penahanan waktu. Dalam pelaksanaanya ada Sembilan (9) kali proses pengujian alat desalinasi dan Sembilan sample yang di ambil untuk di uji hasilnya pada laboratorium. Dari proses Sembilan kali pengujian didapat Sembilan botol sample berisikan air laut dari hasil desalinasi dengan masing-masing volumenya $100 \mathrm{ml} /$ botol. Berikut pembahasan terhadap nilai TDS dan $\mathrm{pH}$ :

Pada hasil uji nilai TDS dengan satuan PPM dilihat dari pengolahan data taguchi Main Effects Plot for SN Rations dan Main Effects Plot for Means, maka didapat pengaruh variasi ketebalan $4 \mathrm{~cm}, 6 \mathrm{~cm}$ dan $8 \mathrm{~cm}$ dimana semakin besar ketebalan filter maka semakin baik nilai TDS yang ada pada air laut hasil desalinasi. Dan Semakin kecil nilai TDS air laut hasil desalinasi maka sangat baik untuk menjadi air yang layak minum. Hal ini menunjukan pada filter bahan tempurung kelapa dengan ketebalan $8 \mathrm{~cm}$ dengan nilai paling rendah TDS $16.720 \mathrm{mg} / \mathrm{l}$. Berikut pada pengaruh variasi pemanasan $50^{\circ} \mathrm{C}, 80^{\circ} \mathrm{C}$ dan $100^{\circ} \mathrm{C}$ semakin besar temperatur pada filter maka semakin kecil nilai TDS yang ada pada air laut hasil desalinasi. Dan Semakin kecil nilai TDS air laut hasil desalinasi maka sangat baik untuk menjadi air yang layak 
minum. Hal ini menunjukan pada filter bahan tempurung kelapa dengan ketebalan $8 \mathrm{~cm}$ temperatur $100^{\circ} \mathrm{C}$ dengan nilai paling rendah TDS $21.000 \mathrm{mg} / \mathrm{l}$. Dan pada pengaruh variasi penahanan waktu 1 menit, 2 menit dan 3 menit semakin lama penahanan waktu pada filter maka semakin rendah nilai TDS yang ada pada air laut hasil desalinasi. Dan semakin rendah nilai TDS air laut hasil desalinasi maka akan memberikan kualitas baik terhadap air hasil desalinasi tersebut. Hal ini menunjukan pada filter bahan tempurung kelapa dengan penahanan waktu 3 menit dengan nilai TDS terendah sebesar $21.000 \mathrm{mg} / \mathrm{l}$.

Pada hasil uji nilai pH dengan satuan asam-basa dilihat dari pengolahan data taguchi Main Effects Plot for SN Rations dan Main Effects Plot for Means, maka didapat pengaruh variasi ketebalan $4 \mathrm{~cm}, 6 \mathrm{~cm}$ dan $8 \mathrm{~cm}$ dimana semakin besar ketebalan filter maka semakin baik nilai $\mathrm{pH}$ yang ada pada air laut hasil desalinasi. Dan Semakin besar nilai $\mathrm{pH}$ air laut hasil desalinasi maka sangat baik untuk menjadi air yang layak minum. Hal ini menunjukan pada filter bahan tempurung kelapa dengan ketebalan $8 \mathrm{~cm}$ dengan nilai $\mathrm{pH}$ paling tinggi 6.859 . Berikut pada pengaruh variasi pemanasan $50^{\circ} \mathrm{C}$, $80^{\circ} \mathrm{C}$ dan $100^{\circ} \mathrm{C}$ semakin besar temperatur pada filter maka semakin kecil nilai $\mathrm{pH}$ yang ada pada air laut hasil desalinasi. Dan Semakin kecil nilai pH air laut hasil desalinasi maka tidak baik untuk menjadi air yang layak minum. Hal ini menunjukan pada filter bahan tempurung kelapa dengan ketebalan $4 \mathrm{~cm}$ temperatur $100^{\circ} \mathrm{C}$ dengan nilai $\mathrm{pH}$ paling rendah 6.789. Dan pada pengaruh variasi penahanan waktu 1 menit, 2 menit dan 3 menit semakin lama penahanan waktu pada filter maka semakin rendah nilai $\mathrm{pH}$ yang ada pada air laut hasil desalinasi. Dan semakin rendah nilai $\mathrm{pH}$ air laut hasil desalinasi maka akan memberikan kualitas kurang baik terhadap air hasil desalinasi tersebut. Hal ini menunjukan pada filter bahan tempurung kelapa dengan penahanan waktu 3 menit dengan nilai $\mathrm{pH}$ terendah 6.179.

\section{KESIMPULAN}

Selama proses penyusunan laporan skripsi sehingga didapat hasil sesuai harapan, maka berikut ini adalah penarikan kesimpulan dari penyusunan skripsi oleh peneliti diantaranya :

- Terdapat Sembilan kali pengujian dengan Sembilan sample hasil dari desalinasi air laut dengan suhu tiap pengujian diantaranya: $50^{\circ} \mathrm{C}, 80^{\circ} \mathrm{C}$ dan $100^{\circ} \mathrm{C}$. Dan waktu penahanan 1 menit, 2 menit dan 3 menit dengan ketebalan filter diantaranya $4 \mathrm{~cm}, 6 \mathrm{~cm}$ dan $8 \mathrm{~cm}$.

- Diketahui dalam proses pengujian Analisa perancangan desalinasi air laut dengan variasi filter tempurung kelapa dan variasi temperatur pemanasan, nilai rata-rata massa masing-masing filter pengujian 1-3 800gr, filter pengujian 4-6 massa 600gr dan filter pengujian 7-9 massa 400gr. Sehingga semakin kecil ketebalan filter semakin berukurang nilai massa bahan yang diperlukan dalam filter.

- Terdapat Sembilan kali pengujian dengan Sembilan sample hasil dari desalinasi air laut dengan kecepatan aliran didapat nilai diantaranya: $0,0018 \mathrm{~m} / \mathrm{s}, 0,0030 \mathrm{~m} / \mathrm{s}, 0,0027 \mathrm{~m} / \mathrm{s}, 0,0026 \mathrm{~m} / \mathrm{s}, 0,0021 \mathrm{~m} / \mathrm{s}, 0,0034 \mathrm{~m} / \mathrm{s}, 0,0035 \mathrm{~m} / \mathrm{s}$, $0,0026 \mathrm{~m} / \mathrm{s}$ dan $0,0022 \mathrm{~m} / \mathrm{s}$ sehingga dapat disimpulkan semakin kecil ketebalan filter maka semakin besar kecepatan alirannya.

- Terdapat Sembilan kali pengujian dengan Sembilan sample hasil dari desalinasi air laut dengan pengujian laboratorium hasil $\mathrm{pH}$ air didapat nilai $\mathrm{pH}$ air laut tertinggi adalah 6,941. Sehingga dapat disimpulkan semakin kecil ketebalan filter batu lava maka semakin besar tingkat keasaman air (asam $\mathrm{pH}<7$ ).

- Terdapat Sembilan kali pengujian dengan Sembilan sample hasil dari desalinasi air laut dengan kemurnian air berdasarkan pengujian laboratorium Total Disolved Solids didapat nilai PPM terbaik yaitu $11.720 \mathrm{mg} / \mathrm{l}$. Sehingga dapat disimpulkan Semakin besar ketebalan filter dalam melakukan proses desalinasi, maka semakin rendah nilai PPM (mg/l) yang dihasilkan.

- Diketahui pada sample pengujian terhadap air laut murni didapat pH air laut 7,938 dan PPM air laut 35.460 $\mathrm{mg} / \mathrm{l}$.

- Diketahui pada sample pengujian sample paduan terhadap air laut murni didapat pH air laut 6,703 dan PPM air laut $21.600 \mathrm{mg} / \mathrm{l}$.

\section{REFERENCES}

[1] Warsinger, David M .; Derek, Emily W .; Swaminathan, Jaichander; Lienhard V, John H. (2017)

[2] Warsinger, David M .; Derek, Emily W .; Nayar, Kishor G .; Maswadeh, Laith A .; Lienhard V, John H. (2016)

[3] Deshmukh, Akshay; Boo, Chanhee; Karanikola, Vasiliki; Lin, Shihong; Straub, Anthony P .; Tong, Tiezheng; Warsinger, David M .; Elimelech, Menachem (2018)

[4] Paradipta, Ika Wahyu. 2015. Statistik Air Bersih 2011-2015. www.bps.go.id/publication/2016/12/14. Published by: Badan Pusat Statistik.

[5] JS, Pujiono. 2015. Kemarau 2015 jadi musim terpanas. www.beritagar.id/sains \& tekno. Published by: Beritatagar.

[6] WHO \& UNICEF. 2015. Water For Life Decade For Action. www.google.com/suling piramida journal pdf. Published by: ojs.unm.ac.id

[7] Rosa, Jorge Luiz; Robin, Alain; Silva, M. B.; Baldan, Carlos Alberto; Peres, Mauro Pedro (2009). "Electrodeposition of copper on titanium wires: Taguchi experimental design approach". Journal of Materials Processing Technology. 209 (3): 1181-1188. doi:10.1016/j.jmatprotec.2008.03.021. 